\title{
THE IMPLEMENTATION OF DEMONSTRATION METHOD TOWARD STUDENT LEARNING OUTCOMES IN BASIC PHYSICS II
}

\author{
Azizahwati $^{{ }^{* 1)}}$, Widya Laila ${ }^{2)}$, Riri Nasirly ${ }^{3)}$ \\ ${ }^{1)}$ Physics Education, University of Riau \\ ${ }^{2,3)}$ Department of Industrial Engineering, High School of Pelalawan Technology \\ e-mail: azizahwati@lecturer.unri.ac.id \\ widya,laila03@st2p-yap.ac.id \\ ririnasirly11@gmail.com
}

\begin{abstract}
This study was aimed to describe the basic physics II learning result of students of Industrial Engineering of Pelalawan Institute of Technology on the electicity material. The subject in this study were the second semester students of Industrial Engineering of Pelalawan Institute of Technology academic year 2017/2018. The instrument which was used to collect the data was the test given after the implementation of the demonstration method. The data was analyzed by using descriptive analysis technique which include student's mastery level. The results of data analysis showed that student learning outcomes were categorized good. The Implementation of demonstration method can improve student learning outcomes on the concept of electricity.
\end{abstract}

Keywords: demonstration method, learning outcomes.

\section{IMPLEMENTASI METODE DEMONSTRASI TERHADAP HASIL BELAJAR MAHASISWA PADA MATA KULIAH FISIKA DASAR II}

\author{
Azizahwati $^{* 1)}$, Widya Laila ${ }^{2)}$, Riri Nasirly \\ ${ }^{1)}$ Pendidikan Fisika, Universtas Riau \\ ${ }^{2,3)}$ Jurusan Teknik Industri, Sekolah Tinggi Teknologi Pelalawan
}

\begin{abstract}
Abstrak
Penelitian ini bertujuan untuk mendeskripsikan hasil belajar fisika dasar II mahasiswa Teknik Industri Sekolah Tinggi Teknologi Pelalawan pada materi kelistrikan. Subjek penelitiannya adalah mahasiswa semester 2 Teknik Industri Sekolah Tinggi Teknologi Pelalawan Ta. 2017/2018. Instrumen yang digunakan untuk pengumpulan data adalah tes hasil belajar yang diberikan sesudah penerapan metode demonstrasi. Data dianalisis dengan menggunakan teknik analisis deskriptif yang meliputi tingkat penguasaan mahasiswa. Hasil analisis data menunjukkan hasil belajar mahasiswa dikategorikan baik. Penerapan metode demonstrasidapat meningkatkan hasil belajar mahasiswa pada konsep kelistrikan.
\end{abstract}

Kata kunci: Metode demonstrasi, hasil belajar. 


\section{Pendahuluan}

Fisika merupakan bagian dari IPA yang meruapakan hasil dari kegiatan manusia yang bersifat aktif dan dinamis serta diperoleh melalui metode tertentu yaitu sistematis, berobjek, bermetode dan berlaku secara universal. Konsep kelistrikan merupakan salah satu bahasan materi yang ada pada mata kuliah Fisika Dasar II. Konsep kelistrikan merupakan salah satu konsep yang sulit untuk dipelajari dan dibelajarkan, sehigga banyak mahasiswa yang megalani kesulitan (Mursalin, 2013).

Kenyataan di lapangan selama memberi kan perkuliahan pada mata kuliah fisika dasar II pada konsep kelistrikan selama ini adalah:

1. Sebagian besar mahasiswa tidak dapat menjawab pertanyaan dari dosen, karena di dianggap sulit.

2. Mahasiswa kurag serius dalam belajar dan mengerjakan soal-soal berkaitan yang diberikan oleh dosen.

3. Rendahnya daya serap mahasiswa teradap mata kuliah prasyarat.

Berdasarkan hal tersebut, maka perlu dicari pemecahan masalahnya. Pentingnya mata kuliah ini khususnya untuk materi kelistrikan merupakan dasar dan jembatan bagi mata kuliah lainnya. Hasil belajar yang optimal dapat dicapai apabila dalam proses perkulihan mahasiswa berperan aktif dan dosen mampu memfasilitasi pembelajaran dengan baik. Pendekatan pengajaran serta metode yang tepat perlu diterapkan agar permasalahan dapat diatasi (Syaiful Sagala, 2009).

Menurut Hatimah (2000), metode dalam pembelajaran mempunyai ruang lingkup sebagai cara dalam: 1) pemberian dorongan, 2) pengungkap tumbuhnya minat belajar, 3) penyampai bahan pelajaran, 4) pencipta iklim belajar yang kondusif, 5) tenaga untuk melahirkan kreativitas belajar, 6) pendorong untuk penilaian diri dalam proses dan hasil belajar, 7) pendorong dalam melengkapi kelemahan belajar.

Salah satu metode pembelajaran yang dapat dilaksanakan untuk mencapai kompetensi dimaksud adalah metode demonstrasi. Metode demonstrasi adalah salah satu teknik mengajar yang dilakukan oleh pengajar untuk memperlihatkan kepada kelas tentang suatu proses atau cara melakukan sesuatu. Metode demonstrasi biasanya diaplikasikan menguna kan alat-alat bantu pengajaran seperti bendabenda minatur, gambar, alat peraga dan lainlain (Hamzah B. Uno, 2010).

Langkah-langkah penerapan metode demonstrasi menurut Annisatul Mufaroka (2009) adalah sebagai berikut: 1) mempersiap kan alat-alat yang diperlukan, 2) guru menjelaskan apa yang direncanakan dan apa yang dikerjakan, 3) guru mendemonstrasikan kepada peserta didik secara perlahan dan memberikan penjelasan, 4) guru mengulang kembali selangkah demi selangkah dan menjelasakan alasan-alasan setiap langkah, 5) Guru menjelaskan kepada siswa agar melaku kan demonstrasi sendiri langkah demi langkah serta memaknainya.

Miftahul Huda (2013) menyatakan bahwa keunggulan metode demonstrasi adalah: 1) Membuat pengajaran menjadi lebih jelas dan konkrit, 2) Memusatkan perhatian, 3) mengarahkan proses belajar siswa pada materi yang sedang dipelajari menjadi lebih terarah, 4) memberi pengalaman dan kesan yang lebih melekat sebagai hasil pembelajaran dalam diri siswa, 5) Membuat siswa lebih mudah memahami apa yang dipelajari, 6) Membuat proses pengajaran lebih menarik, 7) Merangsang siswa untuk aktif mengamati, dan menyesuaikan antara teori dengan kenyataan. 8) Membantu siswa untuk memahami jalannya suatu proses atau kerja suatu benda. 9) Memudahkan berbagai jenis penjelasan. 10) Memperbaiki kesalahan yang terjadi akibat dari ceramah melalui pengamatan dan contoh konkret dengan menghadirkan objek sebenar nya.

Berdasarkan latar belakang permasala han yang telah dijelaskan, maka penelitian ini bertujuan untuk meningkatkan hasil belajar Fisika Dasar II mahasiswa jurusan Teknik Industri melalui penerapan metode demonstrasi.

\section{Bahan dan Metode}

Penelitian ini dilaksanakan pada semester genap 2017/2018. Subjek penelitian yaitu mahasiswa semester 2 Jurusan Teknik 
Industri Sekolah Tinggi Teknologi Pelalawan. Rancangan penelitian yang digunakan adalah The one shot case study. Instrumen yang digunakan untuk pengumpulan data adalah tes hasil belajar yang diberikan sesudah penerapan metode demonstrasi. Data yang diperoleh dianalisis dengan menggunakan teknik anlisis deskriptif untuk menentukan tingkat penguasa an mahasiswa.

Untuk menganalisis tingkat penguasaan mahasiswa, analisis data yang digunakan adalah daya serap mahasiswa. Daya serap adalah kemampuan mahasiswa terhadap materi yang disajikan dalam proses pembelajaran. Untuk mengetahui daya serap yang diperoleh dari hasil belajar digunakan ketentuan menurut persamaan (1).

DayaSerap $=\frac{\text { skor yang diperoleh siswa }}{\text { skor maksimum }} \times 100 \%$

Daya serap mahasiswa didefinisikan sebagai kemampuan menyerap materi yang disajikan dalam proses pembelajaran. Selanjutnya tingkat penguasaan mahasiswa berdasarkan daya serap ditentukan berdasarkan Tabel 1.

Tabel 1. Tingkat penguasaan mahasiswa

\begin{tabular}{|c|c|c|}
\hline $\begin{array}{c}\text { Tingkat } \\
\text { Penguasaan }\end{array}$ & Kriteria & Keterangan \\
\hline$\geq 80-100$ & $\begin{array}{l}\text { Sangat } \\
\text { Baik }\end{array}$ & $\begin{array}{l}\text { Menguasai hampir } \\
\text { semua konsep }\end{array}$ \\
\hline$\geq 70-<80$ & Baik & $\begin{array}{l}\text { Menguasai } \\
\text { sebagian besar } \\
\text { konsep }\end{array}$ \\
\hline$\geq 60-<70$ & Cukup & $\begin{array}{l}\text { Menguasai separoh } \\
\text { konsep }\end{array}$ \\
\hline$\geq 50-<60$ & Kurang & $\begin{array}{l}\text { Menguasai } \\
\text { sebagian kecil } \\
\text { konsep }\end{array}$ \\
\hline$<50$ & $\begin{array}{l}\text { Kurang } \\
\text { Sekali }\end{array}$ & $\begin{array}{l}\text { Hampir tidak } \\
\text { menguasai konsep }\end{array}$ \\
\hline
\end{tabular}

Sumber: Depdiknas (2006).

\section{Hasil dan Pembahasan}

Setelah melakukan penelitian melalui penerapan metode demonstrasi, maka diperoleh hasil seperti pada Tabel 2. Tingkat penguasaan mahasiswa bervariasi mulai dari sangat baik sampai kurang.
Tabel 2. Tingkat Penguasaan Mahasiswa pada Materi Pokok Fisika dasar

\begin{tabular}{|c|c|c|}
\hline $\begin{array}{c}\text { Tingkat } \\
\text { Penguasaan }\end{array}$ & Persentase (\%) & Kriteria \\
\hline$\geq 80-100$ & 39,28 & Sangat Baik \\
\hline$\geq 70-<80$ & 17,86 & Baik \\
\hline$\geq 60-<70$ & 25,00 & Cukup \\
\hline$\geq 50-<60$ & 7,14 & Kurang \\
\hline$<50$ & 10,71 & Kurang Sekali \\
\hline $\begin{array}{l}\text { Rerata daya } \\
\text { serap }\end{array}$ & 70,79 & Baik \\
\hline
\end{tabular}

Rata-rata Daya serap sebesar $70,79 \%$ berada pada kategori baik. Daya serap terbesar berada pada kategori sangat baik (39,28\%). Berdasarkan Tabel 2, mahasiswa yang mengambil mata kuliah ini menguasai sebagian besar konsep kelistrikan. Hal ini mengindikasikan bahwa; 1) mahasiswa termotivasi mengikuti perkuliahan, melalui demonstrasi pembelajaran menjadi lebih menarik. Hal ini disebabkan mahasiswa tidak hanya mendengar, tetapi juga melihat peristiwa yang terjadi. 2) mahasiswa sebagian besar memahami materi kelistrikan. 3) Adanya kaitan sesuatu yang lebih konkret terhadap materi perkuliahan menjadikan mahasiswa lebih memahami konsep. 4) Dalam pembelajaran mahasiswa cenderung lebih aktif untuk mencari tahu informasi yang berkaitan dengan konsep pembelajaran.

Pelaksanaan metode demonstrasi dapat melatihkan kemandirian mahasiswa sehingga dapat meningkatkan hasil belajar mahasiswa pada konsep kelistrikan. Hal ini sejalan dengan hasil yang diperoleh oleh Kinne \& Zacate (2014). Dahyana (2014) dan Fikria Trisnawati (2017) yang menyatakan bahawa melalui metode demonstrasi dapat meningkatkan hasil belajar siswa. Dengan cara mengamati secara langsung siswa akan memiliki kesempatan untuk membandingkan antara teori dan kenyataan.

Fisika yang merupakan bagian dari sains tidak luput dari proses. Penerapan metode demonstrasi dalam pembelajaran memberikan penguasaan keterampilan yag digunakan untuk menggali serta menguasai prosedur untuk menyingkap alam/ lingkungan melalui proses ilmiah. Keterkaitan antara sesuatu yang abstrak menjadi lebih konkrit dalam pembelajaran berdampak pada pembentukan kreativitas dan inovasi yang lebih berarti (Muhibin Syah, 
2000). Metode demonstrasi yang telah dilaksanakan mampu memberikan kesempatan kepada mahasiswa untuk dapat menarik kesimpulan yang benar (Syaiful Sagala, 2008). Hal ini sejalan dengan dimensi dari sains dimana sains sebagai produk bertujan untuk: 1 ) memperoleh penguasaan terhadap fakta, konsep, prinsip dan teori, 2) Kemampuan tentang cara menjelaskan cara untuk menguasai produk sains, 3) penguasaan sains sebagai sesuatu yang komprehensif dan utuh. Berdasarkan hal ini, maka pribadi yang terbentuk akan memiliki: 1) bekal kemampuan dasar untuk keperluan hidupnya, 2) keterampilan dalam mengembang kan dan menerapkan konsep sains, 3) sikap ilmiah sehingga mampu menyelesaikan masalah kehidupan (Ekohariadi, 2009; Firman H, 2007; OECD, 2014).

Dengan menerapkan metode demonstrasi ternyata dapat meningkatkan aktivitas peserta didik sehingga memperoleh hasil belajar yang lebih baik. Partisipasi yang muncul dalam pembelajaran mampu memupuk kerjasama yang harmonis dan mampu menciptakan kedisiplinan kelas dan suasana perkuliahan menjadi demokratis. Aktivitas mahasiswa yang lebih baik terbentuk melalui pembelajaran ini sejalan dengan apa yang dikatakan oleh Miftahul Huda (2013) bahwa terdapat perubahan positif apabila seseorang pendidik mengubah metode pengajaran ke arah yang lebih berpusat pada siswa.

Menurut Agus Suprijono (2013), ada 4 hal penting yang harus dilakukan pelajar agar menjadi pembelajar yang mandiri yaitu; (1) Secara cermat mendiagnosis suatu situasi pembelajaran tertentu, (2) Memilih strategi atau metode belajar tertentu dalam menyelesai kan masalah yang dihadapi, (3) Memonitor keefektifan strategi atau metode tersebut, (4) Cukup termotivasi untuk terlibat dalam situasi belajar sehingga masalah tersebut terselesai kan. Setelah melaksanakan demonstrasi mahasiswa dituntut untuk mengerjakan serangkain tugas. Tugas-tugas yang diberikan selama pembelajaran membuat mahasiswa menjadi lebih aktif dan lebih mandiri.

Sebanyak 7,14\% berada pada tingkat penguasaan yang kurang dan 10,71\% mahasiswa berada pada tingkat penguasaan yang sangat kurang. Hal ini disebabkan oleh masih adanya mahasiswa yang masih bingung dengan pembacaan rangkaian yang berkaitan denga hukum Kirchoff II (Kock, et al., 2014) dan pada kasus rangkaian seri paralel (Bilal \& Erol, 2009). Walaupun mereka sudah mencobakan langsung rangkaian seri dan paralel serta hukum Kirchoff II, tetapi analisis matematika mahasiswa masih perlu dioptimal kan. Upaya pengembangan pembelajaran ke arah yang lebih baik harus terus dilakukan melalui proses yang kreatif, edukatif dan inovatif, sehingga mahasiswa mampu untuk bereksplorasi dan menjadi lebih percaya diri untuk mencapai suatu kompetensi.

\section{Kesimpulan dan Saran}

Berdasarkan hasil penelitian yang telah dicapai, maka dapat disimpulkan bahwa daya serap rata-rata mahasiswa melalui penerapan metode demonstrasi pada konsep kelistrikan adalah $70,79 \%$ dengan kategori baik yang menunjukkan sebagian besar mahasiswa telah menguasai konsep. Melalui penerapan metode demonstrasi dapat meningkatkan hasil belajar mahasiswa pada konsep kelistrikan.

Masih terdapat kekurangan dalam implementasi pemebelajaran dengan metode demonstrasi. Untuk itu, maka diperlukan upaya yang lebih maksimal agar dapat meningkatkan daya serap mahasiswa. Untuk mengatasi tingkat kesulitan mahasiswa, maka penelitian selanjutnya perlu adanya media pembelajaran yang optimal, sehingga hasil yang didapat bisa lebih baik.

\section{Daftar Pustaka}

Agus Suprijono, 2013. Cooperative Learning Teori dan Aplikasi PAIKEM. Pustaka Pelajar, Yogyakarta.

Annisatul Mufaroka, 2009. Strategi Belajar Mengajar. Yogyakarta, Teras.

Bilal, E. \& Erol, M., 2009. Investigating Student's Conceptions of Some Elctricity Concepts. Latin American Journal of Physics Education, 2(3), 174183.

Dahyana, 2014. Penerapan Metode Demonstrasi untuk Meningkatkan Hasil Belajar Siswa dalam Pembelajaran IPA 
Terpadu, Jurnal Nalar Pendidikan, 2 (2), 200-206.

Depdiknas, 2006. Panduan uтum Pengembangan Sistem Assesmen Berbasis Kompetensi (Buku I). Direktorat Jendral pendidikan Tinggi, Jakarta.

Ekohariadi, 2009. Faktor-faktor yang Mempengaruhi Literasi Sains Siswa Indonesia. Jurnal Pendidikan Dasar, 10 (1), 28-41.

Fikria Trisnawati, 2017. Peningkatkan Hasil Belajar IPA melalui Penggunaan Metode Demonstrasi pada Siswa Kelas 4 SD. Satya Widya, 33(1), 37-44.

Firman, H., 2007. Analisis Literasi Sains Berdasarkan Hasil PISA Nasional. Jakarta. Puspendiknas, Jakarta.

Hatimah, 2000. Strategi dan Metode Pembelajaran. Adira, Bandung.

Hamzah, B. Uno, 2010. Perencanaan Pembelajaran. Bumi Aksara, Jakarta.

Kinne, L.J. \& Zacate, M. O., 2014. "The Physics Demonstration Show: A Force for Learning and Increasing Interest in Science?" Delta Journal of Education, 4(1), 38-55.

Kock, Z., Taconis, R., Bolhuis, S., \& Graveimejer, K., 2014. Creating A Culture Of Inquiry In The Classroom While Fostering An Understanding Of Theoretical Concepts In Direct Current Electric Circuits: A Balanced Approach. International Journal of Science and Mathematics Education (IJMSE), 13 (1), 45-69.
Joni Hendri, M. Syukri, \& Tahmid Sabri, 2015. Peningkatan Aktivitas Belajar Siswa dalam Pembelajaran IPA dengan Metode Demonstrasi di Sekolah Dasar,

Miftahul Huda. 2013. Model-Model Pengajaran dan Pembelajaran. Yogyakarta, Pustaka Pelajar.

Mursalin, 2013. Model Remediasi Miskonsepsi Materi Rangkaian Listrik dengan Pendekatan Simulasi Phet. Jurnal Pendidikan Fisika Indonesia. (online), tersedia:

http://journal.unnes.ac.id, diakses 20 November 2013).

OECD, 2014. Education at a Glane 2014: OECD Indicators. OECD Publishing. http://dx.doi.org/10.1787/eag-2014-en[2 April 2015].

Syaiful Sagala, 2009. Konsep dan Makna Pembelajaran: untuk Membantu Memecahkan Problematika Belajar dan Mengajar. Alfabeta, Bandung. 